Joanna Golińska-Pilarek

Uniwersytet Warszawski, Warszawa

ORCID 0000-0001-8546-2615

e-mail: j.golinska@uw.edu.pl

\title{
Filozofia w Polsce po reformie - szanse i wyzwania
}

Ustawa 2.0 wprowadziła wiele zmian prawnych dotyczących różnych obszarów funkcjonowania uczelni wyższych. Odniosę się tylko do jednego obszaru działalności akademickiej, a mianowicie obszaru badawczego, bo wydaje się, że właśnie w tym obszarze Ustawa 2.0 wprowadza najwięcej zmian. Skupię się przede wszystkim na wyzwaniach, jakie stoją dzisiaj przed środowiskiem filozofów polskich, i szansach, jakie stwarza obecna reforma, by tym wyzwaniom sprostać. Zacznę od ogólnych obserwacji, by następnie przejść do wniosków i konkretnych postulatów.

Polska szkoła filozoficzna okresu międzywojennego była fenomenem na skalę światową. Osiągnięcia tej szkoły do dziś mają ogromny wpływ na filozofię. Jestem przekonana, że również obecnie polska filozofia ma w swoim dorobku osiągnięcia wybitne. Największe wyzwanie, jakie moim zdaniem stoi dziś przed środowiskiem filozoficznym $w$ Polsce, to zbudowanie silnych ośrodków filozoficznych, rozpoznawalnych na arenie międzynarodowej. Mamy w tym zakresie ogromny potencjał, a przede wszystkim kapitał, a mimo to żaden ośrodek filozoficzny w Polsce nie zdobył znaczącej pozycji w międzynarodowym środowisku filozoficznym. Przyczyny tej sytuacji są zapewne różne. Wymienię tylko kilka, które mają znaczenie w kontekście ostatniej reformy.

Przyczyn fenomenu polskiej szkoły filozoficznej okresu międzywojennego jest oczywiście wiele, ale niewątpliwie nie byłoby tego sukcesu, gdyby jej członkowie nie publikowali swoich wyników w językach dostępnych dla międzynarodowej społeczności filozoficznej. 
Niestety obecnie dorobek większości polskich filozofów jest w ogóle dla świata niewidoczny. Większość polskich filozofów publikuje prawie wyłącznie w języku polskim w czasopismach, które nie są dostępne szerszej społeczności międzynarodowej. Wielu nigdy nawet nie próbowało publikować poza swoim lokalnym środowiskiem. Jeśli rzeczywiście chcemy, by filozofia polska znaczyła coś na świecie, jeśli chcemy, by nasz głos $\mathrm{w}$ debacie filozoficznej był słyszalny, to musimy zaczać od zmiany środowiskowo akceptowalnych praktyk publikacyjnych. W dyskusjach dotyczących stanu polskiej humanistyki i polskich czasopism z zakresu humanistyki stosunkowo często pojawia się argument, że polscy humaniści tworzą wybitne prace, których poziom nie odbiega (a czasami jest lepszy) od poziomu prac napisanych $w$ językach kongresowych i publikowanych w czasopismach i wydawnictwach międzynarodowych. Dlaczego więc te wybitne prace ukrywamy przed światem?

Trzeba sobie jasno powiedzieć: jeśli nie będziemy udostępniać światu naszych prac, pozostaniemy w tyle i sami na siebie wydamy wyrok. Siłą filozofii w Polsce w kontekście rozmaitych zagrożeń, wynikających z tej reformy czy następnych reform albo z innych globalnych tendencji ograniczania finansowania humanistyki, powinna być przede wszystkim jej silna pozycja na arenie międzynarodowej. Pytanie: jak to zrobić? Jak zmienić obowiązującą dzisiaj w środowisku normę? Pozwolę sobie zacytować fragment artykułu Marii Lewickiej i Tytusa Sosnowskiego, który ukazał się w Forum Akademickim:

Jedna z najbardziej popularnych teorii zmian postaw [...] mówi, że aby zmienić zachowanie, konieczne jest spełnienie trzech kryteriów. Po pierwsze nowe zachowanie musi się człowiekowi opłacać - zyski ze zmiany powinny być większe, a koszty mniejsze niż z trwania przy starym zachowaniu. Po drugie musi istnieć norma społeczna wspierająca zmianę i człowiek musi mieć motywację, żeby tej normie się podporządkować. Wreszcie po trzecie - co wydaje się oczywiste w teorii, ale już nie w praktyce - trzeba umieć wykonać to nowe zachowanie (trzeba wiedzieć, jak to zrobić).

W odniesieniu do interesującego nas tu zachowania, jakim jest publikowanie w międzynarodowych, wysokopunktowanych czasopismach, te trzy punkty oznaczały: (1) konieczność wprowadzenia systemu gratyfikacji (niekoniecznie finansowych), który kompensowałby zmagania z wymagającymi recenzentami, wielokrotne poprawianie tekstu, narażenie na jego odrzucenie; (2) konieczność wypracowania konsensusu środowiskowego odnośnie do tego, co wypada, a co nie wypada w nauce, co jest źródłem prestiżu środowiskowego, a co powodem do wstydu; (3) opanowanie niezbędnego know how, przy czym chodzi nie tylko o opanowanie języka angielskiego, lecz także całego warsztatu publikacyjnego, a więc rozpoznanie rynku istniejących czasopism, opanowanie strategii radzenia sobie $\mathrm{z}$ recenzjami, formułowania odpowiedzi recenzentom, umiejętność amortyzowania wstrząsów, gdy decyzja redakcyjna 
jest negatywna etc. $Z$ tych trzech kryteriów prawdopodobnie obecność normy społecznej jest warunkiem najważniejszym. Na nic się zdadzą gratyfikacje finansowe, jeżeli nie będzie im towarzyszyć akceptowana powszechnie norma społeczna. Z kolei obecność normy i motywacja do podporządkowania się jej w sposób naturalny pociągają za sobą działania na rzecz kryterium trzeciego: opanowania niezbędnego know how ${ }^{1}$.

Zmiana normy publikacyjnej jest moim zdaniem największym wyzwaniem, przed jakim stoi dzisiaj polskie środowisko filozoficzne. Zbyt często ważne i ciekawe badania polskich filozofów prezentowane są tylko w polskich czasopismach i wyłącznie w języku polskim. Ogromną rolę w procesie zmiany normy publikacyjnej może odegrać Komitet Nauk Filozoficznych PAN. To właśnie ta instytucja mogłaby stać się inicjatorem debaty dotyczącej praktyk publikacyjnych filozofów polskich. Debata ta powinna odpowiedzieć na następujące pytania:

(1) Czy środowisko filozoficzne w Polsce widzi potrzebę zmiany praktyk publikacyjnych? - bez powszechnej akceptacji konieczności zmian dalsze działania nie przyniosą spodziewanego efektu.

(2) Jakie są przyczyny, dla których filozofowie polscy rzadko publikują w językach obcych, a jeszcze rzadziej w najlepszych czasopismach?

(3) Jakie działania wspierające publikowanie w językach obcych należy podjąć?

Przejdę teraz do próby odpowiedzi na pytanie, które często pada w dyskusjach dotyczących obecnej reformy i poprzednich reform: czy mamy już w ogóle nie pisać po polsku? I co z polskimi czasopismami?

Uważam, że dyskusja dotycząca polskich czasopism filozoficznych powinna zacząć się od odpowiedzi na pytanie: jaki jest cel istnienia polskich czasopism naukowych z zakresu filozofii? Polskie czasopisma filozoficzne mogą spełniać kilka ważnych funkcji akademickich i społecznych, ale najważniejszym i podstawowym celem istnienia polskich czasopism filozoficznych, o ile mają to być czasopisma naukowe, powinno być publikowanie oryginalnych wyników badań na najwyższym poziomie i w języku dostępnym możliwie najszerszej grupie czytelników, tak jak to robią najlepsze międzynarodowe czasopisma filozoficzne. Nie ma powodu, by polskim czasopismom filozoficznym nadawać jakiś szczególny status, który zwalniałby je z tej podstawowej funkcji czasopisma naukowego. Polskie czasopisma filozoficzne powinny prezentować

1 Maria Lewicka, Tytus Sosnowski, „Psychologii się udało”, Forum Akademickie 9 (2019): https://prenumeruj.forumakademickie.pl/fa/2019/09/psychologii-sie-udalo/; dostęp 15.02.2020. 
światu badania filozoficzne prowadzone w Polsce. Powinny być wizytówką współczesnej filozofii polskiej. To zaś oznacza publikowanie prac w językach właściwych dla danej specjalności filozoficznej. Ponieważ większość badań filozoficznych prowadzonych w Polsce nie dotyczy tematyki specyficznie polskiej, lecz podejmowanej również w innych miejscach na świecie, językiem publikacji nie powinien być polski, tylko ten język, w którym prowadzona jest debata w danej specjalności.

Długofalowym celem powinno być stworzenie przynajmniej jednego polskiego czasopisma filozoficznego (oby więcej) o najwyższym prestiżu naukowym, które stanowiłoby alternatywę dla istniejących czasopism o ugruntowanej wysokiej pozycji międzynarodowej. Stworzenie takiego czasopisma jest zadaniem bardzo ambitnym, ale nie nierealizowalnym, o czym może świadczyć zainteresowanie autorów zagranicznych publikowaniem w tych polskich czasopismach filozoficznych, które jakiś czas temu otworzyły się na teksty niepolskojęzyczne.

Publikowanie w językach kongresowych nie wyklucza jednak wydawania prac również $\mathrm{w}$ języku polskim. Powinniśmy to robić $\mathrm{z}$ wielu powodów. Dzięki publikacjom w języku polskim kształtuje się polska terminologia filozoficzna. Teksty pisane $\mathrm{w}$ języku polskim mogą być przydatne w pracy ze studentami. I w końcu: publikacje w języku polskim popularyzują najnowsze badania filozoficzne wśród czytelników, którzy nie są zawodowymi filozofami. Tego rodzaju działalność jest ważna z powodów społeczno-kulturowych, jednak nie jest to aktywność stricte badawcza, a w związku z tym badacz prowadzący analizy w zakresie filozofii nie może się ograniczać do prezentowania wyników swoich badań grupie zawężonej do filozofów znających język polski.

W Polsce istnieje około 150 czasopism filozoficznych. Być może warto się zastanowić, czy ta liczba nie jest za duża. Wiele obecnie funkcjonujących czasopism filozoficznych powstało w ostatnich latach jako odpowiedź na wymogi parametryzacyjne, często tylko po to, by autorzy mogli cokolwiek i gdziekolwiek opublikować. Jednak niektóre polskie czasopisma filozoficzne wykonały ogromną pracę, by sprostać współczesnym wymogom i standardom przestrzeganym w najlepszych i dobrych czasopismach międzynarodowych. Niestety, większość polskich czasopism filozoficznych ich nie spełnia i ma jeszcze dużo do nadrobienia. Nie ma też środowiskowego konsensusu co do tego, które z polskich czasopism są najbardziej prestiżowe. Ta sytuacja nie tylko utrudnia ocenę czasopism, ale przede wszystkim nie sprzyja budowaniu ich silnej pozycji.

Podsumuję tę część mojego wystąpienia postulatem: środowisko filozofów polskich powinno wypracować mechanizmy i podjąć działania, które będą: (1) sprzyjać publikowaniu badań filozoficznych prowadzonych $\mathrm{w}$ Polsce $\mathrm{w}$ językach kongresowych i na najwyższym poziomie; 
(2) budować silną pozycję polskich czasopism na arenie międzynarodowej.

Jakie szanse stwarza wdrażana obecnie reforma $\mathrm{w}$ tym zakresie? Uważam, że wprowadzone przez Ustawę 2.0 i odpowiednie rozporządzenia zasady ewaluacji naukowej dyscyplin, pomimo wielu wad, takie szanse stwarzają.

Po pierwsze w obowiązujących zasadach ewaluacji nie ma już żadnych mechanizmów, które preferowałyby duże ośrodki. Wprawdzie tego rodzaju zabezpieczenia były obecne już w poprzednich zasadach ewaluacji wprowadzonych przez reformy minister Kudryckiej (ograniczenie do $3 \mathrm{~N}$ uwzględnianych w ewaluacji osiągnięć publikacyjnych czy też obliczanie pewnych wskaźników jednostki proporcjonalnie do wielkości jednostki, np. w zakresie publikacji i pozyskiwanych funduszy z agencji grantowych), jednak pod tym względem obecna reforma idzie dużo dalej. W szczególności w obowiązujących zasadach ewaluacji nie uwzględnia się już uprawnień do nadawania stopni, liczby uzyskanych stopni i tytułów naukowych, mobilności pracowników, udziału w zespołach eksperckich, towarzystwach czy redakcjach czasopism międzynarodowych. Wszystkie te czynniki były uwzględniane w poprzedniej ewaluacji w ramach Kryterium 2 (Potencjał naukowy). Naturalnie to większe metropolitalne ośrodki uzyskiwały $\mathrm{w}$ tym kryterium najlepsze wyniki, co mogło mieć decydujący wpływ na uzyskanie gorszej kategorii przez mniejsze, nie-metropolitalne ośrodki uzyskujące w pozostałych kryteriach podobne wyniki jak ośrodki metropolitalne. Zgodnie z obecnymi zasadami ewaluacji bierze się pod uwagę wyłącznie najlepsze (a nie wszystkie) osiągnięcia publikacyjne (Kryterium 1), fundusze pozyskane z agencji grantowych (Kryterium 2) oraz wpływ prowadzonych badań na społeczeństwo (Kryterium 3). Punkty uzyskane w Kryteriach 1 i 2 są dzielone przez liczbę pracowników z danej dyscypliny, którzy podlegają ewaluacji w danym ośrodku. Ponadto nowa ewaluacja wprowadza ograniczenie liczby uwzględnianych w ewaluacji osiągnięć publikacyjnych jednego pracownika. To zaś oznacza, że o wyniku ewaluacji nie może już decydować względnie duża liczba tzw. lokomotyw publikacyjnych, czyli pracowników publikujących wiele prac w wysokopunktowanych czasopismach. Liczba osiagnięć publikacyjnych "lokomotyw” uwzględnianych w ewaluacji nie może być bowiem większa niż liczba osiągnięć publikacyjnych każdego innego pracownika. Podejrzewam, że to właśnie w ośrodkach metropolitalnych jest takich "lokomotyw” najwięcej, co w poprzednich parametryzacjach mogło zaburzać średnią ocenę takich jednostek.

Wszystko to oznacza, że wielkość ocenianego ośrodka nie ma już żadnego znaczenia w ewaluacji. Mały ośrodek filozoficzny działający poza miastami metropolitalnymi ma (teoretycznie) te same szanse uzyskania dobrego wyniku w ewaluacji naukowej co ośrodek metropolitalny. 
Innymi słowy: z perspektywy ewaluacji każdy ośrodek filozoficzny w Polsce (duży czy mały) będzie zmagał się z podobnymi trudnościami i zagrożeniami. Wynik najbliższej parametryzacji nie jest przesądzony. To przede wszystkim od lokalnych społeczności i kierowników zarządzających tymi społecznościami zależy, jaki wynik te społeczności osiągną.

Po drugie nowe zasady punktowania publikacji niewątpliwie preferują publikacje w czasopismach rozpoznawalnych międzynarodowo (co wcale nie musi oznaczać, że są to wyłącznie czasopisma zagraniczne czy też wyłącznie czasopisma angielskojęzyczne). A zatem z perspektywy ministerialnej ewaluacji bardziej opłaca się publikować w czasopismach i wydawnictwach międzynarodowych. Warto pamiętać, że obowiązujące poprzednio zasady punktacji publikacji, ze względu na małe różnice pomiędzy punktacją słabych polskich czasopism a punktacją najlepszych czasopism międzynarodowych, raczej zniechęcały do prób publikowania międzynarodowo ${ }^{2}$. Nowa lista czasopism, mimo pewnych wad, jest krokiem naprzód w stosunku do obowiązujących wcześniej zasad. Lista czasopism może stanowić czynnik motywujący, choć należy pamiętać, iż podstawowym powodem, dla którego powinniśmy starać się publikować międzynarodowo, jest publikowanie wyników naszych badań dla możliwie najszerszego grona czytelników oraz budowanie na arenie międzynarodowej silnej pozycji filozofii uprawianej w Polsce. Patrząc $\mathrm{z}$ tej perspektywy, nowe zasady ewaluacji są tylko zewnętrznym czynnikiem, który może sprzyjać zmianom w praktykach publikacyjnych, ale nie może być jedyną motywacją do międzynarodowego publikowania. To przede wszystkim od nas zależy, czy norma praktyk publikacyjnych się zmieni. Nie sądzę, by jakikolwiek minister czy system ewaluacji miał $\mathrm{w}$ tym zakresie decydującą moc sprawczą.

Po trzecie nowe zasady ewaluacji $\mathrm{w}$ dużo większym stopniu niż poprzednie doceniają publikowanie monografii. Przypomnę, że filozof, który opublikuje monografię $\mathrm{w}$ wydawnictwie $\mathrm{z}$ poziomu I (wydawnictwa polskie i zagraniczne), otrzyma 100 punktów, tymczasem za monografię $\mathrm{w}$ wydawnictwie $\mathrm{z}$ poziomu II (topowe wydawnictwa międzynarodowe) uzyska aż 300 punktów, a zatem o 100 punktów więcej niż za publikację w najlepszych czasopismach międzynarodowych, takich jak Mind czy Philosophical Studies.

Po czwarte nowe zasady ewaluacji w dużo większym stopniu niż poprzednie sprzyjają jakości, a nie ilości. Ze względu na to, że zgodnie $\mathrm{z}$ obowiązującym rozporządzeniem o ewaluacji naukowej dyscyplin liczba uwzględnianych $\mathrm{w}$ ewaluacji osiągnięć publikacyjnych

2 Cezary Cieśliński, Joanna Golińska-Pilarek, „Jak działać na korzyść humanistyki polskiej?", blog Warsztat Badacza; http://ekulczycki.pl/warsztat_badacza/jakdzialac-na-korzysc-polskiej-humanistyki/, dostęp 09.12.2019. 
jednego pracownika jest z góry ograniczona, przestaje opłacać się publikować dużo. W szczególności bardziej racjonalne jest opublikowanie pracy $\mathrm{w}$ bardzo dobrym czy dobrym czasopiśmie, nawet jeśli miałoby to oznaczać więcej wysiłku i dłuższy czas oczekiwania na publikację, niż kilka prac w słabym czasopiśmie, uzyskanych mniejszym nakładem pracy. Bardziej opłaca się opublikowanie tylko jednej monografii w wydawnictwie z poziomu II niż czterech artykułów w czasopismach lokalnych.

Po piąte wprowadzone zmiany są szansą dla polskich czasopism. Niektóre polskie czasopisma już jakiś czas temu przeszły proces zewnętrznej ewaluacji i znalazły się w bazach WoS i Scopus uwzględnianych przez ministerialny algorytm. Inne czasopisma, nieindeksowane dotychczas $\mathrm{w}$ międzynarodowych bazach, otrzymały dofinansowanie w ramach programu "Wsparcie dla czasopism naukowych" i weszły na ministerialną listę czasopism. Kilkanaście innych polskich czasopism, które tego dofinansowania nie otrzymały, ani też nie są indeksowane $\mathrm{w}$ bazach uwzględnianych przez ministerialny algorytm, znalazło się w wykazie czasopism dzięki decyzji zespołu ds. czasopism w dyscyplinie Filozofia. Teraz jest dobry moment, by dokonać systematycznego audytu polskich czasopism, zdiagnozować ich słabości i wprowadzić działania naprawcze, tak by w przyszłej ewaluacji ich pozycja nie była zagrożona. Warto, by Komitet Nauk Filozoficznych - o ile zdecyduje się na podjęcie odpowiednich działań - wykorzystał wiedzę i dane, które zespół ds. czasopism w dyscyplinie Filozofia zgromadził w trakcie swojej pracy. Niektórzy członkowie zespołu taką pomoc doradczą oferują.

Podjęcie odpowiednich środowiskowych działań w zakresie zmiany praktyk publikacyjnych filozofów polskich i praktyk publikacyjnych stosowanych przez polskie czasopisma ma szanse zaowocować wzmocnieniem pozycji filozofii uprawianej w Polsce, zarówno w kraju, jak i na arenie międzynarodowej. Coraz więcej z nas publikuje międzynarodowo. Polscy filozofowie coraz częściej mogą poszczycić się publikacjami $\mathrm{w}$ najlepszych międzynarodowych czasopismach filozoficznych. Polscy filozofowie publikują monografie $\mathrm{w}$ najbardziej cenionych wydawnictwach, takich jak Cambridge University Press czy Oxford University Press. Publikacji tych nie jest dużo, ale przypadki te pokazuja, że nie jest to niewykonalne. Polscy filozofowie są coraz bardziej skuteczni w pozyskiwaniu funduszy $\mathrm{z}$ agencji czy fundacji międzynarodowych. W tym zakresie w porównaniu do innych humanistów filozofowie polscy mogą pochwalić się sukcesami: na 34 projekty ERC realizowane w Polsce a granty ERC uznawane są za najbardziej prestiżowe granty europejskie -6 to projekty humanistyczne, z czego aż dwa to projekty polskich filozofów. Rosnące umiędzynarodowienie dorobku polskich filozofów jest bardzo dobrym prognostykiem na przyszłość. Trzeba teraz dobrze wykorzystać ten potencjał. Naszą siłą nie jest to, jak bardzo potrafimy 
krzyczeć czy protestować, ani też to, jak bardzo wysublimowane filozoficznie i metodologicznie argumenty wysuniemy przeciwko proponowanym rozmaitym zmianom w przepisach. Naszą siłą może być jedynie silna pozycja polskiej filozofii na arenie międzynarodowej, jako że wkrótce będzie to jedyna karta przetargowa w negocjacjach dotyczących ewentualnych zmian czy korekt $\mathrm{w}$ przepisach dotyczących szkolnictwa i nauki. 